DOI: 10.18276/sip.2017.48/1-07

\title{
Beata Ślusarczyk*
}

Politechnika Częstochowska

\section{POLSKA I SŁOWACJA JAKO MIEJSCA LOKOWANIA CENTRÓW USŁUG WSPÓLNYCH - ANALIZA PORÓWNAWCZA}

\section{STRESZCZENIE}

Centra usług wspólnych są obecnie bardzo popularną formą wsparcia dla wielu przedsiębiorstw w realizacji ich procesów wewnętrznych. Współdzielenie usług, możliwe dzięki standaryzacji procesów, pozwala stosującym je organizacjom redukować koszty, a także osiągać korzyści wynikające z ekonomii skali. Szczególnym miejscem na mapie świata, sprzyjającym funkcjonowaniu właśnie tego typu jednostkom, jest Europa Środkowo-Wschodnia. Wiele czynników przemawia za atrakcyjnością inwestycyjną tego obszaru, m.in. relatywnie niskie koszty pracy, wykształcone zasoby pracownicze czy znajomość języków obcych wśród absolwentów uczelni. Niniejszy artykuł ma na celu porównanie Polski i Słowacji jako krajów mogących stanowić dla siebie alternatywę jako miejsca lokowania centrów usług wspólnych.

Słowa kluczowe: centra usług wspólnych, SSC, Polska, Słowacja, lokalizacja

\section{Wprowadzenie}

Rozwój nowoczesnych technologii oraz związany z nim postęp procesów globalizacyjnych powodują, że współczesne przedsiębiorstwa działają w warunkach coraz większej konkurencji. To sprawia, że konieczne staje się poszukiwanie nowych form organizacji działania, pozwalających na obniżenie kosztów. Rozwiązaniem

\footnotetext{
Adres e-mail: jagoda@zim.pcz.pl
} 
w tym zakresie, które cieszy się obecnie bardzo dużą popularnością, są centra usług wspólnych.

Problem rosnącej konkurencyjności dotyczy jednak nie tylko przedsiębiorstw (Wiśniewska, 2011), lecz również gospodarek narodowych, które rywalizują między sobą o przyciągnięcie jak największej liczby wartościowych inwestorów. Jednym z przykładów takich inwestycji są właśnie centra usług wspólnych.

Niniejszy artykuł ma na celu dokonanie analizy porównawczej Polski i Słowacji jako krajów mogących być dla siebie alternatywą dla lokowania centrów usług wspólnych . Zaprezentowane zostaną informacje dotyczące obecnie funkcjonujących w tych krajach centrów, jednak przede wszystkim scharakteryzowane zostaną podstawowe czynniki mające wpływ na wybór miejsc uruchamiania tego typu jednostek.

\section{Centra Usług Wspólnych - charakterystyka działalności}

Wielu autorów stara się prezentować własne, często specyficzne definicje centrów usług wspólnych, jednak przeważnie zgadzają się ze sobą co do istoty znaczenia tego terminu i przyczyn tworzenia jednostek tego typu. Ogólnie centra usług wspólnych (shared service centres, SSC) zdefiniować można jako jednostki dostarczające organizacjom wsparcie w realizacji ich procesów wewnętrznych. Procesy te są w centrach usług wydzielone i realizowane niezależnie, co przyczynia się nie tylko do maksymalizacji efektywności i podniesienia jakości usług, lecz również generuje wartość dodaną dla organizacji jako całości (Shared Services Centers.., 2014, s. 9; Implementing..., 2000, s. 6). Podstawą tworzenia SSC jest standaryzacja procesów realizowanych wewnątrz organizacji i ich konsolidacja w jednym miejscu, przy czym wcześniej procesy te realizowane były przez wiele różnych jednostek (Boskar, 2008, s. 24).

Współdzielenie usług, możliwe dzięki wspomnianej już wcześniej standaryzacji procesów, pozwala stosującym je organizacjom redukować koszty, a także osiągać korzyści wynikające z ekonomii skali (McIvor, McCracken, McHugh, 2011, s. 449). Liczni autorzy, jak choćby Knol, Janssen, Sol (2014, s. 92), właśnie redukcję kosztów uznają za podstawowy cel tworzenia centrów usług wspólnych. Wang i Wang (2007, s. 281) uważają jednak, iż współdzielenie usług powinno być rozpatrywane w głównej mierze jako wyzwanie związane z przeprojektowaniem organizacji, w mniejszym zaś stopniu jako zjawisko zapobiegania powstawaniu zbędnych kosztów. Wśród innych motywów tworzenia jednostek SSC wymieniane są również 
m.in.: możliwość skoncentrowania się na podstawowej działalności, poprawa jakości świadczonych usług, dostęp do zewnętrznych zasobów czy zwiększenie innowacyjności (Paagman, Tate, Furtmueller, de Bloom, 2015, s. 115; Brzozowska, StarostkaPatyk, 2010).

\section{Wybrane aspekty lokowania centrów usług w Polsce i Słowacji}

Prezentowane badania opierają się na analizie ilościowej, porównującej działalność centrów usług wspólnych w Polsce i na Słowacji w oparciu o opracowania i raporty branżowe'.

Pierwsze centra usług wspólnych powstały w Polsce i na Słowacji już w latach 90. minionego stulecia, niedługo po transformacji ustrojowej. Jednostki SSC mają już zatem w tych krajach ugruntowaną pozycję i obecnie stanowią ważne elementy ich gospodarek. W tabeli 1 przedstawiono podstawowe dane dotyczące centrów usług funkcjonujących w tych państwach.

Tabela 1. Podstawowe dane o centrach usług w Polsce i Słowacji (2015 rok)

\begin{tabular}{|l|c|c|}
\hline & Polska & Słowacja \\
\hline Liczba centrów & 936 & 37 tys. \\
\hline Liczba pracowników & 212 tys. & $1,21 \%$ \\
\hline $\begin{array}{l}\text { Udział pracowników centrów usług } \\
\text { w ogólnej strukturze zatrudnionych } \\
\text { w kraju }\end{array}$ & $1,32 \%$ & Bratysława, Koszyce \\
\hline Główne lokalizacje centrów usług & Kraków, Warszawa, Wrocław & $\begin{array}{c}\text { Bańska Bystrzyca, Nitra, } \\
\text { Presov, Trencin, Trnava }\end{array}$ \\
\hline Lokalizacje rozwijające się & $\begin{array}{c}\text { Poznań, Lublin, Bydgoszcz, } \\
\text { Rzeszów, Szczecin }\end{array}$ & 50 tys. \\
\hline $\begin{array}{l}\text { Prognozowane zatrudnienie } \\
\text { w 2020 roku }\end{array}$ & 300 tys. & 5 \\
\hline
\end{tabular}

Źródło: opracowanie własne na podstawie ABSL (2016); Shared Service \& Business Process Outsourcing Centres in Slovakia (2016); http://openiazoch.zoznam.sk/cl/165896/Snaha-ministerstvapodporit-centra-zdielanych-sluzieb-je-malo-ambiciozna (17.08.2016).

Zarówno w Polsce, jak i na Słowacji głównymi lokalizacjami centrów usług są największe miasta. Jest to zrozumiałe, gdyż duże ośrodki, zwłaszcza te posiadające uczelnie wyższe, są w stanie zagwarantować centrom dostęp do odpowiedniej liczby

1 Dobór krajów w niniejszym artykule wynika z podjętej współpracy w trakcie odbywanego stażu naukowego na Wydziale Zarządzania Uniwersytetu Preszowskiego na Słowacji. 
dobrze wykształconych pracowników, a przy tym są też z reguły najlepiej skomunikowane i oferują dużą ilość powierzchni biurowej do wynajęcia.

Analizując dane dotyczące liczby SSC i zatrudnionych w nich pracowników, zauważyć można jednak ogromną dysproporcję między Polską a Słowacją. Na Słowacji działa obecnie zaledwie 50 jednostek tego typu, podczas gdy w Polsce jest prawie 900 centrów więcej. Podobnie sytuacja kształtuje się w przypadku liczby pracowników. Porównując te parametry, pamiętać jednak należy o znacznej różnicy wielkości obu krajów i liczby ich mieszkańców. Jeśli przeanalizuje się udział pracowników centrów usług w ogólnej strukturze zatrudnionych w obu krajach, uzyskane zostaną podobne wartości. Można zatem wnioskować, że centra usług mają dla rynków pracy w Polsce i Słowacji zbliżone znaczenie. W obu krajach w najbliższych latach prognozuje się również dość znaczny wzrost zatrudnienia w tego typu jednostkach - łącznie ma powstać ok. 100 tys. nowych miejsc pracy, z czego prawie $80 \%$ w Polsce. Na Słowacji, mimo znacznie mniejszego przyrostu prognozowanego zatrudnienia $\mathrm{w}$ jednostkach SSC, może być on jednak zdecydowanie bardziej odczuwalny, gdyż w porównaniu do obecnego poziomu zatrudnienia liczba pracowników zwiększy się o ponad 65\%.

Lokowanie centrów usług wspólnych, jak również wszystkich innych inwestycji zagranicznych w konkretnych krajach, uzależnione jest od wielu czynników. Kluczowe znaczenie ma niewątpliwie ogólna sytuacja ekonomiczna danego państwa, ze szczególnym uwzględnieniem kwestii związanych z produktywnością i kosztami pracy. Wybrane dane ekonomiczne dotyczące Polski i Słowacji przedstawione zostały w tabeli 2 .

Tabela 2. Wybrane dane ekonomiczne Polski i Słowacji (2015 i 2016 rok)

\begin{tabular}{|l|c|c|}
\hline & Polska & Słowacja \\
\hline Wzrost PKB w 2015/2016 & $3,6 \% / 2,8 \%$ & $3,6 \% / 2,5 \%$ \\
\hline Inflacja w 2015 roku & $-0,7 \%$ & $-0,3 \%$ \\
\hline Wartość bezpośrednich inwestycji zagranicznych (mld USD) & 273,7 & 69,76 \\
\hline Poziom bezrobocia rejestrowanego (koniec 2015 roku) & $9,8 \%$ & $10,6 \%$ \\
\hline $\begin{array}{l}\text { Produktywność pracy w 2015 roku (wzrost w stosunku do } \\
\text { roku poprzedniego) }\end{array}$ & 2,1 & 1,9 \\
\hline Koszty pracy (średni godzinny koszt pracy) & 8,6 EUR & 10 EUR \\
\hline Średnie miesięczne wynagrodzenie & 932 EUR & 883 EUR \\
\hline Koszty ubezpieczeń społecznych ponoszone przez pracodawcę & $17,48-20,14 \%$ & $35,2 \%$ \\
\hline
\end{tabular}

Źródło: opracowanie własne na podstawie ABSL (2015), s. 67; GUS (17.08.2016 i 27.06.2017); Investment in Slovakia (2016); Eurostat (17.08.2016), http://countryeconomy.com/gdp/slovakia (29.06.2017). 
Polska i Słowacja charakteryzują się podobnym poziomem rozwoju gospodarczego. W 2015 roku odnotowały taki sam wzrost PKB, a w 2016 roku w obu krajach poziom PKB obniżył się. Ponadto oba kraje zmagały się w 2015 roku z deflacją. Sporą różnicę na korzyść Polski można dostrzec w wartości bezpośrednich inwestycji zagranicznych, jednak wynika to w głównej mierze z różnicy wielkości obu państw.

Skupiając się na danych związanych z rynkiem pracy, również dostrzega się wiele podobieństw. W obu krajach utrzymuje się zbliżony poziom bezrobocia, przy czym nieco lepiej sytuacja wygląda w Polsce, gdzie wskaźnik ten osiągnął na koniec 2015 roku wartość poniżej 10\%. Bardziej niż na Słowacji wzrosła również produktywność pracy, choć różnica $\mathrm{w}$ tym przypadku jest niewielka. $\mathrm{Z}$ punktu widzenia potencjalnych inwestorów na korzyść Polski przemawiają także niższe koszty pracy, choć należy podkreślić, że w obu krajach są one jednymi z najniższych w Europie. Duże dysproporcje można odnotować natomiast w przypadku kosztów ubezpieczeń społecznych ponoszonych przez pracodawcę - znacznie wyższy poziom tych kosztów występuje na Słowacji.

Sytuacja ekonomiczna kraju i kwestie związane z produktywnością pracy czy kosztami ponoszonymi przez pracodawcę są przy podejmowaniu decyzji o wyborze miejsca lokowania centrów usług wspólnych kwestiami bardzo istotnymi, ale nie jedynymi. Równie istotne są choćby: łatwość rozpoczęcia i prowadzenia biznesu w danym kraju, liczba i kompetencje potencjalnych pracowników, dostępność powierzchni biurowej do wynajęcia czy oferowane przez władze zachęty inwestycyjne. Dane dotyczące wskazanych kwestii przedstawiono w tabelach 3-4.

Doskonałych informacji o warunkach prowadzenia biznesu dostarcza opracowywany przez specjalistów z Banku Światowego raport Doing Business (2016). W raporcie dotyczącym 2016 roku Polska zajęła miejsce 25, a Słowacja - 29. Oznacza to, że warunki prowadzenia biznesu w obu krajach są dość zbliżone, zatem w oczach potencjalnych inwestorów mogą być dla siebie alternatywą. W analizie warto jednak dokładniej przyjrzeć się ocenom krajów w poszczególnych podkategoriach. Polska wypada korzystniej od Słowacji w aspektach dotyczących pozyskiwania kredytów, ochrony inwestorów mniejszościowych, płacenia podatków, a także - choć tu różnica jest już znacznie mniejsza - egzekwowania umów. Na Słowacji natomiast łatwiej inwestorom rozpoczynać działalność, uzyskać pozwolenie na budowę czy zarejestrować własność nieruchomości.

Analizując wyniki raportu, warto również zwrócić uwagę na liczbę procedur i czas potrzebny do ich zrealizowania w kwestiach szczególnie interesujących 
z punktu widzenia inwestorów lokujących swoje centra usług wspólnych. W przypadku rozpoczęcia działalności na Słowacji mamy do czynienia z większą liczbą procedur, jednak cały proces trwa prawie trzykrotnie krócej niż w Polsce. Odwrotna sytuacja ma miejsce przy uzyskiwaniu pozwoleń na budowę - to w Polsce jest więcej procedur, jednak czas ich realizacji jest znacznie krótszy, co sprawia, że lepiej wypada w tym porównaniu. Na korzyść Polski przemawiają również kwestie związane z płaceniem podatków, choć tu akurat głównym czynnikiem jest nie liczba płatności i czas na nie przeznaczany (gdyż one są mniejsze na Słowacji), a całkowita stopa procentowa (niższa o ponad 10 punktów procentowych). Można się zatem pokusić o stwierdzenie, że bardziej przyjazne warunki do rozwoju centrów usług wspólnych panują właśnie w Polsce, choć bez wątpienia oba kraje mają jeszcze wiele do zrobienia w kwestii poprawy warunków prowadzenia w nich biznesu.

Tabela 3. Podstawowe informacje dotyczące studentów w Polsce i Słowacji (2015 rok)

\begin{tabular}{|l|c|c|}
\hline & Polska & Słowacja \\
\hline Liczba studentów & 1405000 & 162586 \\
\hline Liczba absolwentów & 395000 & 58089 \\
\hline $\begin{array}{l}\text { Liczba studentów na kierunkach odpowiadających potrzebom jednostek } \\
\text { SSC }\end{array}$ & 556000 & 86407 \\
\hline Odsetek studentów znających język (\%): & \multicolumn{2}{|c|}{9} \\
\hline angielski & 33 & 60 \\
\hline niemiecki & 19 & 12 \\
\hline francuski & 16 & 7 \\
\hline hiszpański & 15 & 4 \\
\hline rosyjski & 33 \\
\hline
\end{tabular}

Źródło: opracowanie własne na podstawie ABSL (2015), s. 20; ABSL (2016), s. 57-58; Shared Service \& Business Process Outsourcing Centres in Slovakia (2016), s. 3; Investment in Slovakia (2016), s. 22.

Liczba studentów i absolwentów jest w Polsce znacznie większa niż na Słowacji, co oczywiście wynika z dużych dysproporcji w liczbie mieszkańców tych krajów. Udział studentów w ogólnej liczbie mieszkańców w tych państwach jest jednak zbliżony: w Polsce wynosi ok. 3,65\%, natomiast na Słowacji nieco ponad 3\%. Na Słowacji relatywnie wyższe jest przy tym dopasowanie do potrzeb jednostek SSC - na kierunkach preferowanych przez te jednostki kształci się ponad połowa studentów, podczas gdy w Polsce jest to około $40 \%$. 
Analiza znajomości języków obcych wśród studentów pokazuje, że w obu krajach głównym językiem obcym jest angielski - zna go ok. 90\% studentów. W przypadku pozostałych języków mamy już do czynienia ze słabszą ich znajomością oraz dużymi dysproporcjami między oboma krajami. Szczególnie widoczne jest to w przypadku języka niemieckiego, którym na Słowacji potrafi posługiwać się aż $60 \%$ studentów, natomiast w Polsce mniej niż 35\%. Język niemiecki jest przy tym jedynym językiem, którym lepiej władają studenci słowaccy niż polscy. W pozostałych przypadkach to w Polsce są one lepiej znane.

Tabela 4. Rynek nieruchomości biurowych w wybranych miastach (2015)

\begin{tabular}{|l|c|c|c|c|c|}
\hline & Kraków & Warszawa & Wrocław & Bratysława & Koszyce \\
\hline Zasoby powierzchni biurowej $\left(\mathrm{m}^{2}\right)$ & 800800 & 4751400 & 724800 & 472000 & 46580 \\
\hline Wskaźnik pustostanu $(\%)$ & 5,7 & 14,1 & 7,3 & 11,59 & 27 \\
\hline Powierzchnia w budowie $\left(\mathrm{m}^{2}\right)$ & 284000 & 662000 & 170000 & 185290 & 10000 \\
\hline
\end{tabular}

Źródło: ABSL (2016), s. 48; Shared Service \& Business Process Outsourcing Centres in Slovakia, (2016), s. 11.

Zdecydowanie większe zasoby powierzchni biurowej oferują miasta polskie. Podobnie sytuacja wygląda w przypadku powierzchni znajdujących się obecnie w budowie. Pomimo większej podaży powierzchni biurowej wskaźnik pustostanów jest w analizowanych polskich miastach niższy niż w miastach słowackich. Wyjątek stanowi tu Warszawa, w przypadku której wskaźnik ten jest wyższy niż w Bratysławie, jednak należy zauważyć, że w stolicy Polski rynek powierzchni biurowej jest dziesięciokrotnie większy niż w stolicy Słowacji.

Dla przyciągnięcia inwestorów lokujących w danym kraju swoje SSC duże znaczenie mają również zachęty inwestycyjne oferowane przez władze państwa. Zestawienie takich udogodnień, stosowanych przez kraje Europy Środkowo-Wschodniej, znaleźć można w raporcie Business Services in Central \& Eastern Europe z 2015 roku. Pomoc państwowa została tam podzielona na trzy główne kategorie: zachęty pieniężne, podatkowe oraz inne.

W Polsce zachęty pieniężne przyjmują formę rządowych dotacji udzielanych na podstawie porozumienia zawartego pomiędzy inwestorem a Ministrem Gospodarki. Poziom wsparcia waha się w granicach ok. $740-3620$ EUR $^{2}$ na jedno miejsce pracy i uzależniony jest m.in. od liczby i jakości stworzonych miejsc pracy oraz typu i za-

2 Kwoty zostały podane w euro, aby można było je porównać z uwarunkowaniami słowackimi. 
awansowania świadczonych procesów. O wsparcie takie mogą ubiegać się jedynie SSC, które utworzą co najmniej 250 nowych miejsc pracy (na okres nie krótszy niż 5 lat), a ich nakłady inwestycyjne będą wyższe niż ok. 348200 EUR. Inwestorzy mogą w Polsce skorzystać także z atrakcyjnych zachęt podatkowych.

Korzystny zestaw zachęt publicznych oferują inwestorom również władze Słowacji. SSC mogą skorzystać z dofinansowania do nowo utworzonych miejsc pracy - wartość takiego wsparcia sięgać może 13100 EUR na jednego zatrudnionego. Dostępnym rozwiązaniem z zakresu zachęt podatkowych jest również częściowe zwolnienie z podatku dochodowego, które, w zależności od strefy, może wynieść maksymalnie 38\% lub nawet 50\% dochodów. By skorzystać z któregoś z tych ułatwień, SSC musi spełnić jednak wiele warunków. Należy stworzyć minimum 40 nowych miejsc pracy, przynajmniej $60 \%$ zatrudnionych musi posiadać wyższe wykształcenie, kwota inwestycji w środki trwałe nie może być niższa niż 400000 EUR, przy czym przynajmniej 200000 EUR musi być pokryte z kapitału własnego. Inną zachętą, która nie jest obłożona tak sprecyzowanymi obostrzeniami, jest możliwość przeniesienia na inwestora własności państwowej lub komunalnej po obniżonej cenie - odbywa się to na podstawie odrębnej umowy z właścicielem.

\section{Podsumowanie}

Centra usług wspólnych są ważnym elementem funkcjonowania wielu współczesnych organizacji. Przyczyniają się one bowiem nie tylko do redukcji kosztów, ale również do uzyskania przewagi konkurencyjnej. Ich istotną zaletą jest również fakt, że mogą być tworzone praktycznie w każdym miejscu na świecie, niezależnie od lokalizacji jednostki macierzystej. Oczywiście lokowanie centrów uwarunkowane jest wieloma czynnikami, które sprawiają, że pewne państwa są bardziej atrakcyjne niż inne. Regionem, w którym w ostatnich latach miały miejsce liczne inwestycje polegające na tworzeniu centrów usług wspólnych, jest Europa Środkowa-Wschodnia, w tym szczególnie Polska i Słowacja. Kraje te mogą pochwalić się wieloma zaletami, dzięki którym są dla wielu inwestorów preferowaną lokalizacją.

Pierwszym czynnikiem decydującym o atrakcyjności Polski i Słowacji jest stabilna sytuacja ekonomiczna z optymistycznymi perspektywami rozwojowymi. Bardzo duże znacznie dla inwestorów mają również niskie w porównaniu z krajami Europy Zachodniej koszty pracy, a także rosnąca produktywność pracy. Istotną przesłanką do lokowania centrów usług wspólnych w tych krajach jest ponadto coraz 
większa łatwość prowadzenia w nich działalności biznesowej potwierdzona w raporcie Banku Światowego. Zarówno Polska, jak i Słowacja mają w tej materii jeszcze wiele do poprawy, co oznacza, że w kwestii przyciągania tego typu inwestorów oba kraje mają jeszcze spore rezerwy.

Ważnym czynnikiem przyciągania do kraju bezpośrednich inwestycji zagranicznych, których przykładem są właśnie centra usług wspólnych, są wszelkiego rodzaju publiczne zachęty stosowane przez rządy oraz samorządy. W Polsce oferowane są w tym zakresie rządowe dopłaty przysługujące na nowo utworzone miejsca pracy, a także możliwość działania w Specjalnej Strefie Ekonomicznej, w której uzyskać można częściowe zwolnienie z podatku CIT. Podobnymi udogodnieniami próbuje się pozyskać inwestorów na Słowacji - również w tym państwie istnieje możliwość uzyskania dofinansowania do nowo utworzonych miejsc pracy oraz częściowe zwolnienie $\mathrm{z}$ podatku dochodowego. $\mathrm{W}$ obu krajach skorzystanie $\mathrm{z}$ tych preferencyjnych warunków działalności uwarunkowane jest spełnieniem określonych wymagań, dotyczących głównie wielkości zainwestowanych środków oraz liczby zatrudnionych dzięki danemu projektowi pracowników.

O atrakcyjności danego kraju dla inwestorów planujących utworzyć swoje centra usług wspólnych decyduje również wiele czynników związanych z jakością zasobów ludzkich oraz rynkiem nieruchomości biurowych. W związku z faktem, że jednostki te świadczą specjalistyczne usługi odbiorcom zlokalizowanym zwykle w różnych krajach, szczególnie ważne są kompetencje językowe potencjalnych pracowników. Większość kadry SSC stanowią osoby z wykształceniem wyższym, dlatego też to studenci są w centrum ich zainteresowania. Zarówno Polska, jak i Słowacja mogą pochwalić się sporą liczbą studentów (ponad 3\% populacji w obu krajach), wśród których praktycznie każdy zna przynajmniej jeden język obcy. Kompetencje potencjalnych pracowników są zatem wysokie, a w połączeniu z niskimi kosztami pracy z pewnością stanowią czynnik przyciągający inwestorów do obu tych państw. Również rynki nieruchomości biurowych w tych krajach spełniają wymagania centrów usług wspólnych, dając przy tym duże możliwości wyboru lokali użytkowych.

Wszystkie te czynniki sprawiają, że i Polska i Słowacja jawią się w oczach jednostek szukających miejsca dla swoich centrów usług wspólnych jako państwa przyjazne tego typu inwestycjom. Polska jako kraj zdecydowanie większy pod względem powierzchni i liczby mieszkańców jest w stanie przyjąć znacznie większą liczbę tego typu jednostek, jednak Słowacja również ma w tym zakresie spore możliwości. Nie da się przy tym jednoznacznie stwierdzić, który z tych krajów oferuje centrom usług wspólnych lepsze warunki funkcjonowania i przyszłego rozwoju, gdyż państwa te 
znajdują na zbliżonym poziomie gospodarczym, a każde z nich dysponuje większymi atutami w innych aspektach.

\section{Literatura}

ABSL (2015). Business Services in Central \& Eastern Europe 2015. Pobrane z: http://www. absl.cz/docs/CEE_report_final.pdf.

ABSL (2016). Sektor nowoczesnych ustug biznesowych w Polsce 2016. Pobrane z: http:// absl.pl/wp-content/uploads/2016/10/Raport_ABSL_2016_PL.pdf.

Boskar, M.A. (2008). Kapitał ludzki jako element zarządzania wiedzą w centrach usług wspólnych. Zeszyty Naukowe Wyższej Szkoły Zarzadzania w Ostrołęce, 6, 21-28.

Brzozowska, A., Starostka-Patyk, M. (2010). Determinants of outsourcing process. W: M. Höck, M. Novicka-Skowron (red.), Produktion und Logistik (s. 3-17). Freiberg: Technische Universität Bergakademie Freiberg Freiberger Forschungshefte.

Doing Business 2016 (2016). International Bank for Reconstruction and Development: Washington. Pobrane z: http://www.doingbusiness.org/ /media/WBG/DoingBusiness/Documents/Annual-Reports/English/DB16-Full-Report.pdf.

Implementing Shared Services Centers (2000). Montvale: Institute of Management Accountants. Pobrane z: https://www.imanet.org.cn/uploads/resource/2015-11/1447061634-11762.pdf.

Investment in Slovakia (2016). KPMG in Slovakia.

Knol, A., Janssen, M., Sol, H. (2014). A taxonomy of management challenges for developing shared services arrangements. European Management Journal, 32, 91-103.

McIvor, R., McCracken, M., McHugh, M. (2011). Creating outsourced shared services arrangements: lessons from the public sector. European Management Journal, 49, 448-461.

Paagman, A., Tate, M., Furtmueller, E., de Bloom, J. (2015). An integrative literature review and empirical validation of motives for introducing shared services in government organizations. International Journal of Information Management, 35 (1), 110-123.

Shared Services Centers 2014 - moving towards centers of excellence (2014). Pobrane z: https://www.pwc.com/sk/en/shared-services-centres/assets/ssc-survey-2014.pdf.

Shared Service \& Business Process Outsourcing Centres in Slovakia (2016). Pobrane z: http:// www.sario.sk/sites/default/files/data/sario-ssc-bpo-centers-in-slovakia-2017-06-12.pdf.

Wang, S., Wang, H. (2007). Shared services beyond sourcing the back offices: Organizational design. Human Systems Management, 26 (4), 281-290.

Wiśniewska, J. (2011). Bezpośrednie inwestycje zagraniczne w procesie kreowania innowacyjności i konkurencyjności przedsiębiorstw. Studia i Prace Wydziału Nauk Ekonomicznych i Zarzadzania, 21, 59-69. 


\title{
POLAND AND SLOVAKIA AS THE LOCATION OF SHARED SERVICES CENTERS - COMPARATIVE ANALYSIS
}

\begin{abstract}
Nowadays, shared service centers are a very popular form of support for many companies in the realization of their internal processes. Sharing services by standardizing processes, allows organizations employing them reduce costs, and achieve benefits of economies of scale. Central and Eastern Europe is a special place on the map of the world, favoring the functioning of this type of units. Many factors support the investment attractiveness of the area, including relatively low labor costs, educated labor resources, or knowledge of foreign languages among university graduates. This article aims to make a comparison of Poland and Slovakia as the countries those can provide beneficial alternatives for shared services locating.
\end{abstract}

Keywords: shared services centers, Poland, Slovakia, location, comparison JEL codes: F23, F62 